\title{
Plasmodiasis in Relation to Haematological Parameters among Children in the Internally Displaced Persons Camps (IDPS) within Maiduguri, Nigeria
}

\author{
Umoru M. Askira, E. S. Marshall, S. A. Onyilokwu, Alhaji Bukar, H. J. Balla, and H. B. Ali
}

\section{ABSTRACT}

\begin{abstract}
Introduction: Malaria parasite is a protozoan disease that is transmitted by female anopheles mosquito which infects humans regardless of age, sex and status. It has a worldwide distribution and often prevalent in the developing countries and areas with poor environmental hygiene this study focuses on the incidence of plasmodiasis in relation to haematological parameters among children in the Internally Displaced Persons (IDPs) camp.
\end{abstract}

Methods: blood samples were collected via venipuncture for thick blood film and was stained with giemsa diluted 1:10 and rapid diagnostic techniques (RDT), while the hematological parameter were analyzed by auto analyzer machine.

Results: a total of two hundred and one (201) samples were obtained from two different camps in the study area. 87 were obtained from Stadium IDPs camp and 114 from Bakassi camp. From the Stadium IDPs camp 25(12.4\%) were malaria positive and $62(30.8 \%)$ were negative. Similarly, from Bakassi IDPs camp, $58(28.9 \%)$ were positive and $56(27.9 \%)$ were negative.

Conclusions: Males were shown to have eosinophilia compared to the females, due to an increase in the eosinophil count in them which can be used to predict the intensity of malaria infection, and a decrease in the eosinophil in females. There was a partial negative correlation due to a decrease in the monocyte and lymphocyte with increasing parasite density count.

Keywords: Malaria, IDPS, Maiduguri, plasmodiasis.
Published Online: October 11, 2021

ISSN: 2684-5199

DOI: $10.24018 /$ ejbio.2021.2.5.265

\section{Umoru M. Askira*}

Department of Medical Laboratory Science, University of Maiduguri, Nigeria (e-mail: mohammedaskirau@gmail.com) E. S. Marshall

Department of Medical Laboratory Science, University of Maiduguri, Nigeria. S. A. Onyilokwu

Department of Medical Laboratory Science, University of Maiduguri, Nigeria. Alhaji Bukar

Department of Medical Laboratory Science, University of Maiduguri, Nigeria. H. J. Balla

Department of Medical Laboratory Science, University of Maiduguri, Nigeria. H. B. Ali

Department of Medical Laboratory Science, University of Maiduguri, Nigeria.

*Corresponding Author

\section{INTRODUCTION}

Plasmodiasis is a disease transmitted by abite of infected mosquito it occurs in Humans and other animals. Severe disease is largely caused by Plasmodium falciparum, while the disease caused by Plasmodium Vivax, Plasmodium ovale and Plasmodium Malariae are generally milder and rarely fatal. Plasmodium knowlesi a zoonotic Malaria parasite that causes Malaria in macaques but can also infect Humans, these species of Plasmodium differ morphology, immunology, geographical distribution, relapsed pattern, incubation time and in drug response [1].

However, evidence have shown that Nigeria has the highest population at risk of Malaria in Africa and therefore most vulnerable to the risk of missing millennium development goal target [2]. Malaria is a major health problem in Nigeria with stable transmission throughout the country. It accounts for about 30percent of hospital admission, and also one of the major causes of death. Approximately $50 \%$ of Nigeria population experience at least one episode per year [2].

Signs and symptoms of Malaria include headache, fever, fatigue, muscular pain, back pain, vomiting, nausea, spleen enlargement, dry cough, sweating, skin chills, shivery, arthralgia (joint pain), anemia, haemoglobinuria, retinal damage and convulsion. Symptoms usually appear between ten and fifteen days after mosquito bites. An individual infected with Plasmodium falciparum, if not treated immediately may have start having complications which may result in experiencing more devastating symptoms like kidney failure, seizures, mental confusion, coma, and death [3].

Internally Displaced Persons (IDPs); simply refers to persons or groups of persons who have been forced or obliged to flee or to leave their homes or places of habitual residence, in particular as a result of or in order to avoid the effects of armed conflict, situations of generalized violence, violations of Human rights or natural or Human-made disasters, and who have not crossed an internationally recognized State border [4].

Changes in Haematological parameters are likely to be influenced by any disease condition including endemic diseases, such as Malaria, that can affect health of mankind with various clinical presentations. Malaria is a major cause of deaths in the tropical area of the world. Two hundred and nineteen million cases were reported worldwide in 2010 . 
Haematological changes are some of the most common complications in Malaria and they play a major role in Malaria pathogenesis. These changes involve the major cell types such as RBCs, leucocytes, and thrombocytes. Malaria infected patients tended to have significantly lower platelets, WBCs, lymphocytes, eosinophils, RBCs and $\mathrm{Hb}$ level, while monocyte and neutrophil counts were significantly higher in comparison to non-Malaria infected patients. One study showed patients with higher WBCs count compared with community controls. The most common complication during Malaria Infection is thrombocytopenia. Persons with platelet counts $<150,000 / \mu \mathrm{L}$ were $12-15$ times more likely to have Malaria Infection than persons with platelet counts > $150,000 / \mu \mathrm{L}$. A previous study found that the ratio of monocytes to lymphocytes correlated with risk of clinical Malaria during follow-up [5].

\section{MATERIALS AND METHOD}

\section{A. Study Area}

This research was carried out among Internally Displaced Persons (IDPs) camp within the city of Maiduguri. Maiduguri is located at longitude $11^{\circ} \mathrm{E}$ and latitude $3^{\circ} \mathrm{N}$ to the North eastern Nigeria and occupies about 70,898 square kilometers. Borno state is bordered by the neighbored by Cameroon and Chad on the East and Niger to the North. Within Nigeria Borno State shares bounder with Adamawa State to the South, Gombe to the West and Yobe to the North-West. The warm climate has a mean temperature of $38^{\circ} \mathrm{C}$; the hottest months are March, April and May with a temperature of 30 ${ }^{\circ} \mathrm{C}$ to $40{ }^{\circ} \mathrm{C}$. The rainy season starts from June and last for about four (4) months [6].

\section{B. Ethical Consideration}

Ethical approval was obtained from the ethical committee of Borno state ministry of health, Maiduguri prior to the commencement of sampling.

\section{Inclusion Criteria}

Children between the age of 0-12 years old of both sexes living in IDPS camp.

\section{Exclusion Criteria}

Children on antimalarial therapy and those above the age of 12 years old.

\section{E. Sample Collection}

Venous blood sample were collected from the subjects using vacutainer needle and syring and was immediately transferred into an ethylene diamine tetra-acetic acid (EDTA) container and was labeled appropriately.

\section{MATERIALS AND REAGENTS}

\section{A. Giemsa Staining}

working solution was prepared from the stock solution by diluting it at $1: 10$ concentration, $1 \mathrm{ml}$ of the Giemsa stock solution was dispense in $9 \mathrm{ml}$ of buffered distilled water.

Thick blood film was made for each sample and air dried; it was flooded with the diluted Giemsa stain. The preparation was allowed to stain for 10mins. It was later washed off using phosphate buffered distilled water. The back of the slide was wiped to remove excess stain. It was allowed to air dry. It was then examined under microscope using X100 oil immersion objective lens.

\section{B. Identification of Parasites from Blood Film}

The parasites identified were counted on a slide against 200 WBCs for each of the specimen. Then, the result was calculated for the density of parasites per $\mu$ l of blood using the formula:

$$
\text { Parasites } / \mu l=\frac{\text { Number of Parasite counted }}{200 W B C} \times 8000(d f)
$$

\section{Rapid Diagnostic Test (RDT)}

Detection of histidine rich protein (HRP-II) antigen and Lactate dehydrogenase (pLDH) from malaria plasmodium falciparum in human was carried out by Malaria HRP-II (p.f) and pLDH (p.f) Antigen Rapid Test kid as specified by the manufacturer.

\section{Haematological Parameters Investigation}

Hematological parameters such as White Blood Cell (WBC) Count, Packed Cell Volume (PCV) estimation, and Differential Leukocyte Counts were carried out using hematology auto-analyzer machine.

\section{E. Data Analysis}

The data obtained were analyzed using Statistical Package for Social Sciences (SPSS) version 16.0. Pearson correlation analysis was used to test the association between two continuous variables. For all statistical tests, $\mathrm{P}<0.05$ was considered as statistically significant. Finally, all results were described and presented using tables and figures.

\section{RESUlts}

A total number of two hundred and one (201) subjects were recruited for this study from two different IDPs camp within Maiduguri Metropolitan Council. 87(43.3\%) Stadium IDPs camp and 114(56.7\%) from Bakassi IDPs camp. 114(56.7\%) males, $87(43.3 \%)$ females, the mean age range was $8.35 \pm 2.49$, the clinical details shows those with diarrhea $3(1.5 \%)$, fever $61(30.3 \%)$, fever and diarrhea $1(0.5 \%)$, fever and headache $14(7.0 \%)$, fever and vomiting $3(1.5 \%)$, headache $15(7.5 \%)$, vomiting $1(0.5 \%)$ and $103(51.2 \%)$ were asymptomatic Prevalence of Plasmodiasis was 48(23.9\%) positive and $153(76.1 \%)$ negative for histidine rich protein while 30(14.9\%) positive and 171(85.0\%) negative for lactate dehydrogenase Rapid Diagnostic Test. The parasite density count was $1064.35,42(20.9 \%)$ of the positive sample were graded,$+ 21(10.4 \%)$ positive were graded,$++ 20(10.0 \%)$ positive samples were graded +++ parasite grading. $118(58.7 \%$ ) samples were tested negative for Plasmodiasis Prevalence of Plasmodiasis among children in individual IDP camps; $87(43.3 \%)$ samples were collected in stadium IDP camp, $5(2.5 \%)$ positive for histidine rich protein rapid diagnostic test and $1(0.5 \%)$ was positive for lactate dehydrogenase rapid diagnostic test, mean parasite density count is $415.38 \pm 251.48,18(9.0 \%)$ positive samples have + , $6(3.0 \%)$ positive samples have,$++ 1(0.5)$ positive sample 
have +++ parasite grading and $62(30.8 \%)$ were negative. $114(56.7 \%)$ samples were collected in Bakassi IDP camp, $43(21.4 \%)$ positive for histidine rich protein rapid diagnostic test and 29(14.4\%) positive for lactate dehydrogenase rapid diagnostic test, mean parasite density count is $1320 \pm 2660.30$ $24(11.9 \%)$ positive samples have,$+ 15(7.5 \%)$ positive samples have,$+++ 19(9.5 \%)$ positive samples have +++ parasite grading while $56(27.9 \%)$ are negative. Hematological parameters of children in IDP camp diagnosed with Plasmodiasis; the mean packed cell volume of those with Plasmodiasis is $35.40 \pm 5.85$, mean WBC count is $4.05 \pm 2.30$, mean neutrophil count is $28.26 \pm 19.52$, mean eosinophil count is $3.64 \pm 4.72$, mean basophil count is $3.5 \pm 3.26$, mean monocyte count is $15.51 \pm 6.72$ mean lymphocyte count is $48.5 \pm 15.04$ Comparison of hematological parameters among children of individual IDP camps diagnosed with Plasmodiasis; the age of the patients in both camps and prevalence of Plasmodiasis is not significantly different $(\mathrm{P}=0.21)$. The prevalence of Plasmodiasis in both IDP camps in relation to the parasite density count is significant $(\mathrm{P}=0.008)$. The prevalence of Plasmodiasis in relation to white blood cell count is not significant $(\mathrm{P}=0.353)$. A significant association $(\mathrm{P} \leq 0.001)$ between the packed cell volume, neutrophils, eosinophils, basophils and lymphocytes counts and the prevalence of Plasmodiasis was observed. The monocytes count in both camps and prevalence of Plasmodiasis is not significantly different $(\mathrm{P}=0.899)$.

Comparison of hematological parameters among male and female children of the IDP camps diagnosed with Plasmodiasis; The Prevalence of Plasmodiasis in both IDP camps among male and female in relation to age, packed cell volume, parasite density, white blood cell, neutrophils, basophils, monocyte, and lymphocyte are statistically not significant. However, eosinophil's level was statistically significant due to an increase in male and a decrease in female.

Pearson correlation between the parasite density and hematological parameters of monocytes and lymphocyte have no significant difference at $(\mathrm{P}<0.05)$. No relationship between age, packed cell volume, white blood cell, neutrophil, eosinophil, basophil, and parasite density.

TABLE I: DEMOGRAPHIC DISTRIBUTION OF ALL CHILDREN FROM THE IDP

\begin{tabular}{lc}
\multicolumn{2}{c}{ CAMPS } \\
\hline \multicolumn{1}{c}{ Parameters } & Values $(\mathrm{n}=201)$ \\
\hline Age $($ years $)$ & $8.35 \pm 2.49$ \\
Gender & $114(56.7 \%)$ \\
Males & $87(43.3 \%)$ \\
Females & $3(1.5 \%)$ \\
Clinical History & $61(30.3 \%)$ \\
Diarrhea & $1(0.5 \%)$ \\
Fever & $14(7.0 \%)$ \\
Fever and Diarrhea & $3(1.5 \%)$ \\
Fever and Headache & $15(7.5 \%)$ \\
Fever and Vomiting & $1(0.5 \%)$ \\
Headache & $103(51.2 \%)$ \\
Vomiting &
\end{tabular}

TABLE II: DEMOGRAPHIC DISTRIBUTION OF CHILDREN FROM INDIVIDUAL

\begin{tabular}{|c|c|c|c|}
\hline \multicolumn{4}{|c|}{ IDP CAMP } \\
\hline \multirow{2}{*}{ S/No } & \multirow{2}{*}{ Parameters } & Stadium IDP Camp & Bakassi IDP \\
\hline & & $(\mathrm{n}=87)$ & $(n=114)$ \\
\hline 1 & Age (Years) & $8.17 \pm 2.54$ & $8.49 \pm 2.45$ \\
\hline \multirow[t]{3}{*}{2} & Gender & & \\
\hline & Males & $52(25.9 \%)$ & $62(30.8 \%)$ \\
\hline & Females & $35(17.4 \%)$ & $52(26.9 \%)$ \\
\hline \multirow[t]{9}{*}{3} & Clinical History & & \\
\hline & Diarrhea & $3(1.5 \%)$ & $1(0.5 \%)$ \\
\hline & Fever & $16(8.0 \%)$ & $45(22.4 \%)$ \\
\hline & $\begin{array}{l}\text { Fever and } \\
\text { Diarrhea }\end{array}$ & 0 & $1(0.5 \%)$ \\
\hline & $\begin{array}{l}\text { Fever and } \\
\text { Headache }\end{array}$ & $1(0.5 \%)$ & $13(6.5 \%)$ \\
\hline & $\begin{array}{l}\text { Fever and } \\
\text { Vomiting }\end{array}$ & 0 & $3(1.5 \%)$ \\
\hline & Headache & $6(3.0 \%)$ & $9(4.5 \%)$ \\
\hline & Vomiting & 0 & $1(0.5 \%)$ \\
\hline & Asymptomatic & $62(30.8 \%)$ & $41(20.4 \%)$ \\
\hline
\end{tabular}

TABLE III: PREVALENCE OF PlaSMOdiasis AMONG ALL THE CHILDREN IN THE STUDY AREA

\begin{tabular}{cccc}
\hline S/No & Parameter & $\begin{array}{c}\text { Results }(\mathrm{n}=201) \\
\text { Positive }\end{array}$ & Negative \\
\hline 1 & Serology RDT (HRP) & $48(23.9 \%)$ & $153(76.1 \%)$ \\
2 & Serology RDT (LDH) & $30(14.9 \%)$ & $171(85.0 \%)$ \\
3 & Parasite Density Count & 1064.35 & Nil \\
4 & Microscopic Grading MP & & \\
& $1+$ & $42(20.9 \%)$ & - \\
& $2+$ & $21(10.4 \%)$ & - \\
& $3+$ & $20(10.0 \%)$ & - \\
& Negative & - & $118(58.7 \%)$ \\
\hline
\end{tabular}

TABLE IV: PREVALENCE OF PLASMODIASIS AMONG CHILDREN IN INDIVIDUAL IDP CAMPS

\begin{tabular}{|c|c|c|c|}
\hline S/No & Parameters & $\begin{array}{c}\text { Stadium IDP } \\
\text { Camp }(n=87)\end{array}$ & $\begin{array}{c}\text { Bakassi IDP Camp } \\
(\mathrm{n}=114)\end{array}$ \\
\hline 1 & Serology RDT (HRP) & $5(2.5 \%)$ & $43(21.4 \%)$ \\
\hline 2 & Serology RDT (LDH) & $1(0.5 \%)$ & $29(14.4 \%)$ \\
\hline 3 & Parasite Density Count & $415.38 \pm 251.48$ & $1320 \pm 2660.30$ \\
\hline \multirow[t]{5}{*}{4} & Microscopic Grading MF & & \\
\hline & $1+$ & $18(9.0 \%)$ & $24(11.9 \%)$ \\
\hline & $2+$ & $6(3.0 \%)$ & $15(7.5 \%)$ \\
\hline & $3+$ & $1(0.5 \%)$ & $19(9.5 \%)$ \\
\hline & Negative & $62(30.8 \%)$ & $56(27.9 \%)$ \\
\hline
\end{tabular}

TABLE V: HEMATOLOGICAL PARAMETERS OF CHILDREN IN IDP CAMP

\begin{tabular}{ccc}
\multicolumn{3}{c}{ DIAGNOSED WITH PLASMODIASIS } \\
\hline S/No & Parameters & Value $(\mathrm{n}=92)$ \\
\hline 1 & Packed Cell Volume (\%) & $35.40 \pm 5.85$ \\
2 & White Blood Cell Count & $4.05 \pm 2.30$ \\
3 & Neutrophil (\%) & $28.26 \pm 19.52$ \\
4 & Eosinophil (\%) & $3.64 \pm 4.72$ \\
5 & Basophil (\%) & $3.5 \pm 3.26$ \\
6 & Monocyte (\%) & $15.51 \pm 6.72$ \\
7 & Lymphocyte (\%) & $48.5 \pm 15.04$ \\
\hline
\end{tabular}

TABLE VI: COMPARISON OF HEMATOLOGICAL PARAMETERS AMONG CHILDREN OF INDIVIDUAL IDP CAMPS DIAGNOSED WITH PLASMODIASIS

\begin{tabular}{ccccc}
\hline S/No & Parameters & $\begin{array}{c}\text { Stadium IDP Camp } \\
(\mathrm{n}=26)\end{array}$ & $\begin{array}{c}\text { Bakassi IDP } \\
\text { Camp (66) }\end{array}$ & p-value \\
\hline 1 & Age (years) & $9.27 \pm 2.62$ & $8.5 \pm 2.61$ & 0.210 \\
2 & $\begin{array}{c}\text { Parasite Density } \\
\text { Count (parasite/ } \mu 1)\end{array}$ & $415.38 \pm 251.48$ & $1320 \pm 2660.30$ & 0.008 \\
& Packed Cell Volume & $38.02 \pm 3.40$ & $34.37 \pm 6.29$ & 0.001 \\
3 & $(\%)$ & & & \\
& White Blood Cell & $3.78 \pm .30$ & $4.16 \pm 2.59$ & 0.353 \\
4 & Count & $13.22 \pm 7.55$ & $34.18 \pm 19.63$ & 0.000 \\
5 & Neutrophil (\%) & $7.28 \pm 5.64$ & $2.21 \pm 3.40$ & 0.000 \\
6 & Eosinophil (\%) & $5.63 \pm 3.59$ & $2.66 \pm 2.73$ & 0.001 \\
7 & Basophil (\%) & $15.39 \pm 4.55$ & $15.55 \pm 7.44$ & 0.899 \\
8 & Monocyte (\%) & $58.05 \pm 9.36$ & $44.74 \pm 15.24$ & 0.000 \\
9 & Lymphocyte (\%) & & & \\
\hline \multicolumn{7}{c}{} & & & & \\
\hline
\end{tabular}


TABLE VII: COMPARISON OF HEMATOLOGICAL PARAMETERS AMONG MALE AND FEMALE CHILDREN OF THE IDP CAMPS DIAGNOSED WITH

\begin{tabular}{|c|c|c|c|c|}
\hline \multicolumn{5}{|c|}{ PLASMODIASIS } \\
\hline S/No & Parameters & $\begin{array}{c}\text { Male } \\
\text { Children }(n=49)\end{array}$ & $\begin{array}{c}\text { Female } \\
\text { Children }(n=43)\end{array}$ & $\mathrm{p}$-value \\
\hline 1 & Age (years) & $9.06 \pm 2.47$ & $8.32 \pm 2.76$ & 0.184 \\
\hline & Parasite Density & & & \\
\hline 2 & $\begin{array}{c}\text { Count } \\
\text { (parasite/ } / \mu 1)\end{array}$ & $1315.92 \pm 2887.23$ & $777.67 \pm 1291.89$ & 0.243 \\
\hline 3 & $\begin{array}{l}\text { Packed Cell } \\
\text { Volume }(\%)\end{array}$ & $36.34 \pm 4.72$ & $34.33 \pm 6.82$ & 0.108 \\
\hline 4 & $\begin{array}{l}\text { White Blood } \\
\text { Cell Count }\end{array}$ & $4.11 \pm 2.31$ & $3.99 \pm 2.32$ & 0.799 \\
\hline 5 & Neutrophil (\%) & $25.76 \pm 18.52$ & $31.11 \pm 20.44$ & 0.194 \\
\hline 6 & Eosinophil (\%) & $4.75 \pm 5.33$ & $2.38 \pm 3.56$ & 0.013 \\
\hline 7 & Basophil (\%) & $3.66 \pm 3.42$ & $3.31 \pm 3.11$ & 0.602 \\
\hline 8 & Monocyte (\%) & $15.74 \pm 7.14$ & $15.24 \pm 6.29$ & 0.705 \\
\hline 9 & $\begin{array}{c}\text { Lymphocyte } \\
(\%)\end{array}$ & $48.72 \pm 14.07$ & $48.25 \pm 16.25$ & 0.884 \\
\hline
\end{tabular}

TABLE VIII: PEARSON CORRELATION OF PARASITE DENSITY AND

\begin{tabular}{|c|c|c|c|}
\hline S/No & $\begin{array}{l}\text { IEMATOLOGICA } \\
\text { Parameters }\end{array}$ & $\begin{array}{l}\text { L PARAMETERS } \\
\text { Pearson } \\
\text { Coefficient (r) }\end{array}$ & p-value \\
\hline 1 & Age (years) & 0.150 & 0.154 \\
\hline 2 & $\begin{array}{l}\text { Packed Cell } \\
\text { Volume (\%) }\end{array}$ & -0.150 & 0.154 \\
\hline 3 & $\begin{array}{l}\text { White Blood } \\
\text { Cell Count }\end{array}$ & 0.063 & 0.554 \\
\hline 4 & Neutrophil (\%) & 0.153 & 0.145 \\
\hline 5 & Eosinophil (\%) & -0.197 & 0.060 \\
\hline 6 & Basophil (\%) & -0.200 & 0.056 \\
\hline 7 & Monocyte (\%) & -0.224 & 0.032 \\
\hline 8 & $\begin{array}{c}\text { Lymphocyte } \\
(\%)\end{array}$ & -0.232 & 0.025 \\
\hline
\end{tabular}

\section{DISCUSSION}

A total of eighty seven (87) children were recruited for this study from Stadium camp, 25(12.4\%) were positive, and $62(30.8 \%)$ were negative having mean parasite density count of 415.38 \pm 251.48 . And from Bakassi camp, 58(28.9\%) positive for Malaria and 56(27.9\%) were negative with mean density count $1320 \pm 2660.30$. These occurrences of parasites could be as a result of absence of acquired immunity which makes them susceptible to the Infection [7].

Based on the data obtained, it shows that the camp with the highest prevalence is the Bakassi IDPs camp with prevalence of 58(50.9\%) as positive for Malaria and 56(27.9\%) negative which is lower (70.8\%) than that reported by [8].

The comparison of hematological parameters among children of the two IDP camps shows a significant difference with the parasite density, packed cell volume, neutrophil, eosinophil, basophil, and lymphocytes. This is similar with studies conducted by [9]. The low PCV among female may reflect Anaemia which is often due to the parasitized red cells, is similar with a report of Bhawna et al. [10] which showed parasitaemia and hematological alterations in Malaria. The level of neutrophil in the patient were found to be significantly lower in male than female which is in line with the report of Senthilkumaar et al. [11]. The decreased eosinophils count in Bakassi camp is an agreement with the previous studies [12]. The significant lymphocyte and basophil had good sensitivities but lacked specificity to accurately diagnose Malaria. There was no significant difference in age, white blood cell count (WBC), and monocyte found between the two camps. These findings are similar with the study conducted by [13] which reported no significant difference in WBC count. It was also reported a high number of monocyte count in patients with uncomplicated Malaria [12]. However, the complicated form of malaria seen in this study is in contrast to a previous study that was reported with a low monocyte count [14]. The findings are consistent with [15] but none of these studies showed the prognostic power of high monocyte count. Children with decreased monocyte count were three times more likely to have malaria parasite than children with normal monocytes. Based on the evaluation of hematological parameters and Plasmodiasis among male and female children in the IDP camps, there was only a significant difference in eosinophil and is in agreement with the studies carried out by [12]. This may suggest suppressed eosinophils production released from the bone marrow that enhanced peripheral removal. Infection with plasmodiasis based on sex of the children in the study area has no relationship with the packed cell volume, total white blood cell, and lypmphocyte. These findings are steady with the reports on hematological values that showed no significant on gender variation [16]. White blood cell, lymphocyte, with increased the parasite density in male than female was observed. These findings are in line with report of [17].

\section{CONCLUSION}

Plasmodiasis have shown significant changes in hematological parameters among children living IDPs camp in Maiduguri Nigeria. However, Bakassi camp has demonstrated the highest infection rate; this could be as a result of its over population, lack of preventive measures by the children of this camp. Stagnant water is also left unattended to there by forming a breeding ground for mosquitoes. Children infected with different the parasites exhibit important changes and differences in hematological parameters with high eosinophils level which is the most important changes in male in both IDPs camps.

\section{RECOMMENDATION}

It is recommended that: More attention should be given by government and non-governmental organization (NGOs) to the IDPs camps on the preventive measures to Malaria, especially in areas of awareness on the importance of using treated mosquito net, as well as protection from bite of Malaria vector. Microscopy (thick film) diagnosis of Malaria should be practiced by the health workers in various camp as well as other health institute as it is shown to be more specific and sensitive compared to the rapid diagnostic technique. Policy on Malaria control should be advocated.

\section{REFERENCES}

[1] AMCA, Mosquito-Borne Diseases, American Mosquito Control Association ${ }^{\circledR}$ Mount Laurel $\mathrm{Nj}$, Usa, Retrieved from: Www. Mosquito.Org/Mosquito-Borne-Diseases., (March 11, 2016). And Practice of Infectious Diseases. 9(7):275, 2014.

[2] LSM. Malaria Control Program, Lagos State ministry of health.www.lagosstateministryofhealth.com/programme_info.php. Retrieved 11th march, 2016.

[3] J. David, E. C. Anaso, L. N. Ozurumba, "Prevalence of Malaria in a Study Population in Maiduguri, Nigeria. Symptomatic Manifestation 
and Public Health Implications," Greener Journal of Biological Sciences. Vol. 6(5), pp. 103-111, 2016.

[4] T. Deng, P. Yang, D. Zhao, P. Feng, D. Pine, B. F. Chmelka, G. D. Stucky, "Hierarchically ordered oxides," Science, vol. 282(5397), pp. 2244-2246, 1998.

[5] M. Kotepui, Bhukdee Phunphuech, Nuoil Phiwklam, Chaowanee Chupeerac and Suwit Duangmano, "Effect of Malarial Infection on Haematological Parameters in Population near Thailand-Myanmar Border M," Journal of Malaria, 13:218, 2014.

[6] Nigeria Gallery, National Population Commission, $2^{\text {nd }}$ quarter, Vol 7(9), pp. 2346, 2017

[7] R. N. Kamwi, J. K. E. Mfune, G. P. Kaaya, J. B. Jonazi, "Seasonal Variation in the Prevalence of Malaria and Vector Species in Northern Namibia," Journal of Entomology and Nematology, vol. 9(5), pp. 42 $48,2013$.

[8] C. A. Oyinbo, "Secondary injury mechanisms in traumatic spinal cord injury: a nugget of this multiply cascade," Acta Neurobiol Exp (Wars), vol. 71(2), pp. 281-99, 2011.

[9] Mckenzie Fe, Prudhomma Wa, Magil Aj, Jr Fomey, B. Permpanich, C. Lucas, "White Blood Cell Counts and Malaria," J Infect Dis, vol. 192, pp. 323-330, 2000. Pmd: 15962228.

[10] S. Bhawna, A. Bharti, K. Yorkshire, A. Reena, "Parasitemia and Hematological alterations in Malaria: a study from the highly affected zones in India," Iranian Journal of Pathology, vol. 8, pp. 1-8, 2013.

[11] P. Senthilkumaar, S. Sarojini, "Hematological Studies in Malaria Affected Patients in North China, Tamil Nadu," Euro J Exp Bio, vol. 3, pp. 199-205, 2013.

[12] A. Abdalla, "Peripheral Blood and Bone Marrow Leucocyte in Gambia Children with Malaria: Numerical Changes and Evalaution of Phagocytosis," Ann Trop Paediatr., vol. 8, pp. 250-258, 1998.

[13] L. A. Bashawri, A. A Mandil, A. A., Bahnassy, \& M. A. Ahmed, "Malaria: Hematological Aspects," Ann Saudi Med, vol. 22, pp. 372376, 2002.

[14] S. Ladhan, B. Lowe, A. O. Cole, K. Kowuondo, C. R. Newton, "Changes in White Cells and Platelets in Children with Falciparum Malaria: Relationship to Disease Outcome," Br J Haematol, pp. 839847, 2002. 10.1046 Ij.1365- 2141.2002.03904.X.

[15] L. M. Erhart, K. Yingyuen, N. Chuanak, N. Buathong, A. Laoboonchai, R. S. Miller, S. R. Meshnick, R. A. Gasser, C. Wongsrichanalai, "Hematological and Clinical Indices of Malaria in Semi Immune Population of Western Thailand," Ann J Med Hygiene, vol. 70, pp. 814, 2004.

[16] D. N. Dapper, C. A. Nwauche, I. M. Siminialayi, "Some Hematological Reference Values for Pre-Primary and Primary School Aged Children in Port Harcourt, Nigeria," Niger J Clin Pract, vol. 12, pp. 262-7, 2009.

[17] R. Maina, D. Walsh, C. Gadd, G. Hongo, J. Waitumbi, L. Otieno, "Impact of Plasmodium Falciparum Infection on Haematological Parameters in Children Living in Western Kenya," Malaria J, vol. 9, pp. 53-54, 2010.

[18] B. Morassin, R. Fabre, A. Berry, J. F. Magnaval, "One year's experience with the polymerase chain reaction as a routine method for the diagnosis of imported malaria," American Journal of Tropical Medical Hygiene, vol. 9(66), pp. 503-508, 2005.

[19] O. L. George, I. C. Ewelike-Ezean, "Haematological Changes in Children with Malaria Infection in Nigeria," J Med Med Sci, vol. 2, pp.768-71, 2011.

[20] R. Romi, F. Severini, L. Toma, "Cold Acclimation and Overwintering of Female Aedes Albopictus in Roma," Journal of the American Mosquito Control Association, vol. 22 (1), pp. 149-151, 2006.

[21] WHO. World Malaria Report 2019. 2019. Retrieved From: Www.Who.Int/News-Room/Feature-Stories/Detail/World-MalariaReport- 2019.

[22] D. C. Warhurst, J. E. Williams, “ACP Broadsheet no 148. July 1996. Laboratory diagnosis of malaria," Journal of clinical pathology, vol. 49(7), p. 533, 1996.

[23] World Health Organization. Malaria Campaign. Saving Young Lives. 2017. Retrieved from: Www.Who.Int/Malaria/News/2017/SmcCampaign- Nigeria/En/. 